\title{
Concentration of trans-vaccenic and rumenic acids in the milk from grazing cows supplemented with palm oil, rice bran or whole cottonseed
}

\author{
Gastón Adolfo Castaño1, Martha Lucía Pabón², Juan Evangelista Carulla²
}

\author{
${ }^{1}$ Universidad Santa Rosa de Cabal-Unisarc, Colombia \\ 2 Universidad Nacional de Colombia Sede Bogotá, Colombia.
}

\begin{abstract}
The changes in the concentration of trans-vaccenic $\left(\mathrm{C} 18: 1_{t-11}\right)$ and rumenic $\left(\mathrm{C} 18: 2_{c-9, t-11}\right)$ acids in the milk from cows grazing on Pennisetum clandestinum, fed a supplement containing palm oil, rice bran or whole cottonseed were evaluated. Three supplements were assessed: one control supplement containing palm oil (C), with a low concentration of linoleic acid mainly from palm oil, and two supplements containing rice bran (RB) or whole cottonseed (CS) as the main source of linoleic acid. Six Holstein cows (4.2 \pm 1.7 years of age, $532.5 \pm 50.7 \mathrm{~kg} \mathrm{BW}, 125 \pm 29$ days in milk and a milk yield of $21.7 \pm 5.8 \mathrm{~kg} \mathrm{~d}^{-1}$; Mean $\pm \mathrm{SD}$ ) were assigned to each treatment using a double $3 \times 3 \times 3$ Latin Square Design. Compared with treatment $\mathrm{C}$, the milk fat concentrations of trans-vaccenic acid ( 31.1 and $23.8 \mathrm{~g} \mathrm{~kg}^{-1}$ of fatty acids for RB and C, respectively), rumenic acid (14.1 and $11.3 \mathrm{~g} \mathrm{~kg}^{-1}$ of fatty acid for $\mathrm{RB}$ and $\mathrm{C}$, respectively) and unsaturated fatty acids (348.7 and $325.4 \mathrm{~g} \mathrm{~kg}^{-1}$ of fatty acid for RB and C, respectively) were higher for RB. Compared with $\mathrm{C}$ and CS treatments, the $\Delta^{9}$-desaturase index was higher for RB $(0.37,0.35$ and 0.34 for RB, C and CS, respectively) and the thrombogenicity index was lower ( $3.09,3.43$ and 3.50 for RB, C and CS, respectively). The atherogenicity index was lower for RB treatment compared with C, but not compared with CS $(1.85,2.03,1.97$ for RB, C and CS, respectively). Supplementing rice bran to grazing dairy cows is a good alternative for producing a kind of milk beneficial to human health, due to its higher concentrations of trans-vaccenic and rumenic acids, unsaturated fatty acids and lower thrombogenicity and atherogenicity indexes.
\end{abstract}

Key Words: conjugated linoleic acid, dairy cow, linoleic acid, milk fatty acid

\section{Introduction}

Trans-vaccenic (TVA; C18:1 ${ }_{\mathrm{t}-11}$ ) and rumenic (RU; C18:2 $2_{c-9, t-11}$ ) fatty acids (FA) are found in milk fat and have been considered as functional compounds. They have been reported as being anticarcinogenic (Ip et al., 1999; Park et al., 2001), antiatherogenic and antidiabetogenic (Houseknecht et al., 1998; Munday et al., 1999). These acids also regulate the immune system and increase bone mineralization (Jensen, 2002).

The milk concentration of RU and TVA acids is mainly affected by diet (Khanal and Olson, 2004), and supplementation with lipid sources containing unsaturated FA increases such acids concentration (Dhiman et al., 2000; Khanal and Olson, 2004). The effect of oils on the concentration of TVA and RU in milk differs depending on their source (Bharathan et al., 2008; Bouattour et al., 2008; Flowers et al., 2008). Fat sources, rich in linoleic acid (LI)

Received August 12, 2013 and accepted January 30, 2014

Corresponding author: jecarullaf@unal.edu.co

http://dx.doi.org/10.1590/S1516-35982014000600006

Copyright $@ 2014$ Sociedade Brasileira de Zootecnia. This is an Open Access article distributed under the terms of the Creative Commons Attribution Non-Commercial License, which permits unrestricted non-commercial use, distribution, and reproduction in any medium, provided the original work is properly cited. produce more TVA and RU than those containing linolenic acid (LN) (Bu et al., 2007).

The forage-to-concentrate ratio (Ueda et al., 2003; Loor et al., 2005b) and forage species (Mel'uchová et al., 2008; Vasta et al., 2008) are factors related to diet affecting milk fat concentration of TVA and RU. The concentration of these FA in milk is also influenced by the feeding systems (grazing or TMR) used (Kelly et al., 1998; Schroeder et al., 2003; Khanal et al., 2008).

Rice bran and whole cottonseed are frequently used in Colombia for preparing feeding supplements for dairy cows. These resources are rich in LI, 360 to $420 \mathrm{~g} \mathrm{~kg}^{-1}$ of FA for rice bran (de Campos et al., 2007) and $573 \mathrm{~g} \mathrm{~kg}^{-1}$ of FA for whole cottonseed (Dhiman et al., 1999; Khanal and Olson, 2004), and this is why they may be used to produce milk with a high level of TVA and RU. We found no reports in the literature assessing these resources as feed in grazing dairy cows to change the milk FA profile. In Colombian tropical high lands, milk production is based on grazing systems in which kikuyo (Pennisetum clandestinum) is the main grass (Correa et al., 2008), having a LN proportion in lipids between 530 to $595 \mathrm{~g} \mathrm{~kg}^{-1}$ of FA (Aguilar et al., 2009). Grazing on $P$. clandestinum and supplementing with lipids from a supplement (a fat intake from the supplement of near $670 \mathrm{~g} \mathrm{~kg}^{-1}$ of total fat intake) are characteristics of specialized 
livestock in the Bogotá Plateau (Colombia), suggesting this system has high potential to produce milk rich in TVA and RU acids.

We evaluated the changes in the concentration of TVA and RU acids in the milk from dairy cows grazing on P. clandestinum, and supplemented with palm oil, rice bran or whole cottonseed.

\section{Material and Methods}

All the experimental procedures were approved by the Bioethics Committee of Facultad de Medicina Veterinaria y de Zootecnia (School of Veterinary Medicine and Animal Production; Act 001 of 2009) of Universidad Nacional de Colombia. This experiment was carried out between May and July 2009. Average temperature is $13{ }^{\circ} \mathrm{C}$ (with variations from 0 to $20^{\circ} \mathrm{C}$ ); relative humidity ranges from 80 to $85 \%$; and average yearly precipitation is $900 \mathrm{~mm} \mathrm{yr}^{-1}$, with two rainy seasons (April to May and September to November). The experiment term was $84 \mathrm{~d}$, divided into three periods of $28 \mathrm{~d}$ each ( $20 \mathrm{~d}$ of adjustment to experimental diets, and a collection period of $8 \mathrm{~d}$ ). The treatments consisted of three supplements: a control supplement (C) with a low level of LI, mainly coming from palm oil, and two supplements with similar concentrations of LI, mainly coming from rice bran (RB) or from whole cottonseed (CS; Tables 1 and 2). Three $\mathrm{kg} \mathrm{d}^{-1}$ of supplement, $60 \mathrm{~g}$ of mineral salt and $5 \mathrm{~g}$ of $\mathrm{Cr}_{2} \mathrm{O}_{3}$ were offered to grazing cows during each one of two milking processes $(05.00$ and $14.00 \mathrm{~h})$.

Table 1 - Ingredient and chemical composition of supplements

\begin{tabular}{|c|c|c|c|}
\hline & Palm oil & Rice bran & Cottonseed \\
\hline \multicolumn{4}{|l|}{ Ingredient, $\mathrm{g} \mathrm{kg}^{-1}$ as fed } \\
\hline Rice bran & - & 471.7 & - \\
\hline Cottonseed & - & - & 279.8 \\
\hline Palm oil & 79.9 & 10.0 & 47.7 \\
\hline Soybean meal & 286.5 & 236.9 & 213.0 \\
\hline Cassava & 299.5 & 95.5 & 306.1 \\
\hline Wheat bran & 1.9 & 1.5 & 3.0 \\
\hline Palm meal & 51.0 & 129.4 & - \\
\hline Cocoa hulls & 226.2 & - & 95.4 \\
\hline Cane molasses & 50.0 & 50.0 & 50.0 \\
\hline Vitamin and mineral premix & 5.0 & 5.0 & 5.0 \\
\hline \multicolumn{4}{|l|}{ Chemical composition } \\
\hline Dry matter, $\mathrm{g} \mathrm{kg}^{-1}$ as fed & 894.2 & 881.3 & 897.0 \\
\hline Crude protein, $\mathrm{g} \mathrm{kg}^{-1}$ of DM & 158.8 & 183.5 & 218.5 \\
\hline $\mathrm{NDF}^{1}, \mathrm{~g} \mathrm{~kg}^{-1}$ of DM & 225.8 & 248.0 & 207.8 \\
\hline $\mathrm{ADF}^{1}, \mathrm{~g} \mathrm{~kg}^{-1}$ of DM & 203.1 & 148.9 & 188.7 \\
\hline Lignin, $\mathrm{g} \mathrm{kg}^{-1}$ of DM & 98.8 & 91.3 & 96.9 \\
\hline $\mathrm{NSC}^{1}, \mathrm{~g} \mathrm{~kg}^{-1}$ of $\mathrm{DM}$ & 408.2 & 380.1 & 381.1 \\
\hline Ether extract, $\mathrm{g} \mathrm{kg}^{-1}$ of DM & 116.3 & 102.8 & 114.0 \\
\hline Ash, $\mathrm{g} \mathrm{kg}^{-1}$ of DM & 90.9 & 85.6 & 78.6 \\
\hline $\mathrm{NE}_{\mathrm{L}}{ }^{2}$, Mcal kg ${ }^{-1}$ of DM & 1.97 & 1.94 & 2.09 \\
\hline
\end{tabular}

DM - dry matter, NDF - neutral detergent fiber, ADF - acid detergent fiber, NSC - non-structural carbohydrates.

${ }^{1}$ Adjusted by N (NRC, 2001).

${ }^{2}$ Net energy for lactation estimated at $1 \mathrm{X}$ maintenance intake (NRC, 2001).
Six Holstein cows $(533 \pm 51 \mathrm{~kg}$ BW, $4.2 \pm 1.7$ years of age, $125 \pm 29$ days in milk, milk daily production of $21.7 \pm 5.8 \mathrm{~kg}$; Mean \pm SD) were randomly assigned to each treatment using a double $3 \times 3 \times 3$ Latin Square Design ( 3 cows $\times 3$ treatments $\times 3$ periods).

Pasture was cut $50 \mathrm{~d}$ before the experiment and $\mathrm{N}$ fertilization was applied after $5 \mathrm{~d}\left(46 \mathrm{~kg}\right.$ of $\left.\mathrm{N} \mathrm{ha}^{-1}\right)$. The animals grazed in a 2.5 ha plot of $P$. clandestinum under strip system, moving the cord twice a day (morning and evening). A pasture proportion of low, medium and large amounts of forage, according to its height, was established and used to calculate the forage mass. To estimate the total available biomass, three squares of $0.5 \mathrm{~m}^{2}$ each, representative of each height, were used to determine the average of each production level, which was multiplied by the proportion of each pasture level. To determine the daily offer and the plot size, a Global Positioning System GPSMAP 76CSx (Garmin Ltda., Kansas, EUA) was used to measure the forage areas. The grazing area was adjusted to ensure a daily offer of $40 \mathrm{~g} \mathrm{~kg}^{-1}$ of BW. On day 28 in each period, the animals were weighed immediately after their morning milking $(05.00 \mathrm{~h})$ and body condition score (BCS) was evaluated according to Edmonson et al. (1989).

The milk resulting from each milking (morning and afternoon) was weighted and mixed proportionally until reaching a volume of $200 \mathrm{~mL}$, which was divided into two aliquots of $100 \mathrm{~mL}$ each. Sixty milligrams of potassium dichromate were added to one aliquot and then frozen at $-20{ }^{\circ} \mathrm{C}$. The other aliquot was used to determine its concentration of fat.

On days 20 and 27, forage samples (approximately $500 \mathrm{~g})$ were collected simulating animal bite and using a hand plucking system (Cook, 1964; Muir, 2002). The samples collected were vacuum-packed, preserved at $-20{ }^{\circ} \mathrm{C}$, lyophilized (Martin Christ Alpha 1-4LD Plus), and ground using a $1 \mathrm{~mm}$ sieve Romer grinder. Forage samples were taken on days 13,16, 19, 22, 25 and 28 , dried for $48 \mathrm{~h}$ at $60{ }^{\circ} \mathrm{C}$, ground using a $1 \mathrm{~mm}$ sieve Romer grinder, and

Table 2 - Fatty acid (FA) profile of forage and supplements

\begin{tabular}{lcccc}
\hline & & \multicolumn{3}{c}{ Supplements } \\
\cline { 3 - 5 } FA, g kg ${ }^{-1}$ of FA & Kikuyo & Palm oil & Rice bran & Cottonseed \\
\hline C10:0 & & 2.0 & - & 0.3 \\
C12:0 & - & 18.5 & 8.5 & 6.0 \\
C14:0 & 27.8 & 16.6 & 7.1 & 7.5 \\
C16:0 & 9.4 & 322.9 & 225.9 & 245.4 \\
C16:1 & 243.9 & 3.9 & 1.6 & 3.0 \\
C18:0 & 19.7 & 75.7 & 28.3 & 50.4 \\
C18:1 & 68.8 & 382.4 & 382.5 & 318.2 \\
C18:1 & 29.1 & 5.0 & 5.5 & 5.1 \\
C18:-11 & - & 144.2 & 302.7 & 342.8 \\
C18:3 ${ }_{c-9, c-12}$ & 105.5 & 8.1 & 13.3 & 10.0 \\
Others & 368.8 & 20.7 & 24.4 & 15.0
\end{tabular}


homogenously mixed to obtain a composite sample that was used to determine the indigestible ADF (iADF).

A sample of each supplement was collected (approximately $500 \mathrm{~g}$ ), then ground in a $1 \mathrm{~mm}$ sieve Romer grinder. Supplement orts were collected between days 21 and 28 , weighed, and stored at $-8{ }^{\circ} \mathrm{C}$ until determining their DM.

Samples of ruminal fluid $(350 \mathrm{~mL})$ were collected on day 25 using an oro-ruminal probe (Haumptner $\left.{ }^{\mathbb{R}}\right)$. The first $250 \mathrm{~mL}$ were discarded and the remaining $100 \mathrm{~mL}$ were filtered using two layers of cheese cloth. An aliquot was used to measure $\mathrm{pH}$ by a potentiometer (Beckman). Another sample was acidified with hydrochloric acid (Huang et al., 2009), frozen at $-20{ }^{\circ} \mathrm{C}$ and used to determine the ammonium content.

Between days 22 and 27, two daily samples of feces were collected $(05.00 \mathrm{~h}$ and $13.00 \mathrm{~h})$, conserved at $-20^{\circ} \mathrm{C}$, dried $\left(60{ }^{\circ} \mathrm{C}\right.$ for $\left.48 \mathrm{~h}\right)$, ground using a $1 \mathrm{~mm}$ sieve Romer grinder and homogenously mixed, obtaining a composite sample for each animal.

Milk fat was extracted according to Hurley et al. (1987) and Díaz-González et al. (2002). One hundred milliliters of milk were centrifuged (15 $\mathrm{min}$ at $3,000 \mathrm{rpm}$ ) and the aqueous phase was discarded. Fifteen milliliters of a detergent solution ( $50 \mathrm{~g}$ of sodium hexametaphosphate and $24 \mathrm{~mL}$ of Tritón X-100 dissolved in $1 \mathrm{~L}$ of water) were added to the creamy supernatant. The solution was shaken twice and placed into a water bath $\left(90^{\circ} \mathrm{C}\right.$ for $\left.10 \mathrm{~min}\right)$. The upper fraction containing milk fat was carefully removed using a micropipette, and then stored at $-20{ }^{\circ} \mathrm{C}$. An aliquot of fat $(100 \mu \mathrm{L})$ was solubilized in a $1 \mathrm{~mL}$ solution of chloroform:methanol $(1: 1 \mathrm{v} / \mathrm{v})$. To methylate FA, $20 \mu \mathrm{L}$ of a fat solution were placed in a vial with conic inserts, and $20 \mu \mathrm{L}$ of methyl esterification reagent Meth-Prep II $(0.2 \mathrm{M}$ m-trifluoromethylphenyl-trimethylammonium hydroxide in methanol, Alltech Associates Inc., Deerfield, IL, USA) and $160 \mu \mathrm{L}$ of chloroform:methanol $(1: 1 \mathrm{v} / \mathrm{v})$ were added. Supplement fat was extracted according to Folch et al. (1957) and the same procedure described for milk was used for the methylation of FA.

Forage fat extraction and the methylation of FA were performed using a modification of the Garces and Mancha (1993) and Yamasaki et al. (1999) procedures. Absolute methanol $(2,150 \mu \mathrm{L}), 990 \mu \mathrm{L}$ toluene, $66 \mu \mathrm{L}$ sulfuric acid $98 \%, 1,000 \mu \mathrm{L}$ of $\mathrm{N}, \mathrm{N}$-dimethylformamide and $2 \mathrm{~mL}$ of n-hexane were added. This mixture was placed into a water bath $\left(80{ }^{\circ} \mathrm{C}\right.$ for $\left.2 \mathrm{~h}\right)$, left there for $5-10 \mathrm{~min}$, stirred and the hexane supernatant was then recovered. Hexane was evaporated under nitrogen, and $300 \mu \mathrm{L}$ of dichloromethane were added to the tube.
Fatty acid methyl esters were quantified using gas chromatography with a Shimadzu GC-2014, AOC-20i injector and an AOC-20C auto sampler. Fatty acid methyl esters were separated in a capillary column (Restek Rt-2560; $100 \mathrm{~m} \times 0.25 \mathrm{~mm}$ i.d. $\times 0.2 \mu \mathrm{m}$ layer $)$. The injector and the FID temperatures were $260{ }^{\circ} \mathrm{C}$ and $270{ }^{\circ} \mathrm{C}$, respectively; the temperature program was: $140{ }^{\circ} \mathrm{C}$ for $5 \mathrm{~min}$, increased by $4{ }^{\circ} \mathrm{C} \mathrm{min}^{-1}$, increased to $190{ }^{\circ} \mathrm{C}$ and left for $32.5 \mathrm{~min}$. Split ratio was 1:100 and He was used as a gas carrier with a pressure of 40.4 psi. Retention times were compared with standards (Food Industry FAMEX Mix cat 35077).

Dry matter (AOAC-930.15; AOAC, 2010), ash (AOAC942.05; AOAC, 2010) and CP according to Kjeldahl method (AOAC-2001.11; AOAC, 2010) were determined for milk, forage and supplements. Dry matter was determined for supplement orts.

Milk fat was determined according to the Gerber method (AOAC-200.18; AOAC, 2010) and lactose was estimated according Lynch et al. (2007): lactose $=100-$ $\%$ fat $-\% \mathrm{CP}-\%$ ash.

Ether extract (AOAC-930.39; AOAC, 2010), NDF corrected for N (NDFn), ADF corrected for N (ADFn; Van Soest et al., 1991; NRC, 2001), lignin (Van Soest et al., 1991), neutral detergent fiber insoluble nitrogen (NDIN), acid detergent insoluble nitrogen (ADIN; Licitra et al., 1996) and AADF (Sunvold and Cochran, 1991) were determined for forage and supplements. Non-structural carbohydrates corrected for $\mathrm{N}$ (NSCn) and $\mathrm{NE}_{\mathrm{L}}$ were estimated according to NRC (2001).

Fresh samples of ruminal fluid were used to measure $\mathrm{pH}$ (Beckman pHmeter) and frozen samples were used to determine ammonium, using the distillation procedure of the Kjeldahl method (AOAC-2001.11; AOAC, 2010).

The indigestible acid detergent fiber of feces was determined by the Sunvold and Cochran (1991) procedure and $\mathrm{Cr}$ by atomic absorption with a Shimadzu AA-7000 (Williams et al., 1962).

Forage intake was determined using $\mathrm{Cr}_{2} \mathrm{O}_{3}$ as an external indigestible marker (Holden et al., 1994), and iADF as an internal indigestible marker (Sunvold and Cochran, 1991). Feces production $\left(\mathrm{kg} \mathrm{d}^{-1}\right)$ was determined according to Holden et al. (1994) and using a Cr recovery rate of 0.794 (Correa et al., 2009): $\mathrm{FP}=\mathrm{EMD} \times \mathrm{R} \times\left[\mathrm{EM}_{\mathrm{F}}\right]^{-1} \times 1,000^{-1}$, in which $\mathrm{FP}=$ feces production $\left(\mathrm{kg} \mathrm{d}^{-1}\right)$; EMD $=$ external marker

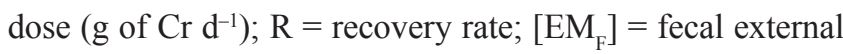
market concentration ( $\mathrm{g}$ of $\mathrm{Cr} \mathrm{g}^{-1}$ of DM).

Forage intake was calculated according Aguilar et al. (2009): $\mathrm{FoI}=\left(\mathrm{FP} \times[\mathrm{iADF}]_{\mathrm{F}}-\mathrm{SI} \times[\mathrm{iADF}]_{\mathrm{S}}\right) \times[\mathrm{iADF}]_{\mathrm{Fo}}{ }^{-1}$, in which $\mathrm{FoI}=$ forage intake $\left(\mathrm{kg}\right.$ of $\left.\mathrm{DM} \mathrm{d} \mathrm{d}^{-1}\right) ; \mathrm{FP}=$ feces production $\left(\mathrm{kg}\right.$ of $\left.\mathrm{DM} \mathrm{d}^{-1}\right) ;[\mathrm{iADF}]_{\mathrm{F}},[\mathrm{iADF}]_{\mathrm{S}}$ and $[\mathrm{iADF}]_{\mathrm{Fo}}$ $=$ feces, supplement and forage $\mathrm{iADF}$ concentrations, 
respectively ( $\mathrm{g}$ of $\mathrm{iADF} \mathrm{g}^{-1}$ of $\left.\mathrm{DM}\right)$; and $\mathrm{SI}=$ supplement intake $\left(\mathrm{kg}\right.$ of $\left.\mathrm{DM} \mathrm{d}^{-1}\right)$.

Fatty acid intake was determined according to the following equation: $\mathrm{FAI}=\left(\mathrm{FoI} \times[\mathrm{TFA}]_{\mathrm{Fo}} \times[\mathrm{FA}]_{\mathrm{Fo}}\right)+\left(\mathrm{SI} \times[\mathrm{TFA}]_{\mathrm{S}}\right.$ $\left.\times[\mathrm{FA}]_{\mathrm{S}}\right)$, in which FAI $=\mathrm{FA}$ intake $\left(\mathrm{g}\right.$ of FA d $\left.{ }^{-1}\right) ; \mathrm{FoI}$ and $\mathrm{SI}=$ forage and supplement intakes, respectively $\left(\mathrm{kg}\right.$ of $\left.\mathrm{DM} \mathrm{d}^{-1}\right)$; $[\mathrm{TFA}]_{\mathrm{Fo}}$ and $[\mathrm{TFA}]_{\mathrm{S}}=$ total FA concentrations in forage and supplement, respectively ( $\mathrm{g}$ of total $\mathrm{FA} \mathrm{g}^{-1}$ of DM); $[\mathrm{FA}]_{\mathrm{Fo}}$ and $[\mathrm{FA}]_{\mathrm{S}}=$ specific FA concentrations in forage and concentrate, respectively ( $\mathrm{g}$ of specific $\mathrm{FA} \mathrm{g}^{-1}$ of total FA). Total FA intake was estimated according to Allen (2000).

The index of $\Delta^{9}$-desaturase activity was calculated according to Gagliostro et al. (2006). Atherogenicity (AI) and thrombogenicity (TI) indexes were determined according to Ulbricht and Southgate (1991).

Data were subjected to analysis of variance for a double $3 \times 3 \times 3$ Latin Square Design using the GLM procedure of
SAS (Statistical Analysis System, version 9.0) according to the following model: $y_{i j(k) m}=\mu+\Upsilon_{m}+\eta(\Upsilon)_{i m}+\lambda(\Upsilon)_{j m}+$ $\tau_{(k)}+\varepsilon_{i j(k) m}$, in which: $y_{i j(k) m}=$ dependent variable; $\mu=$ overall mean; $\Upsilon_{m}=$ effect of square $m ; \eta(\Upsilon)_{\text {im }}=$ effect of period $i$ within square $m ; \lambda(\Upsilon)_{j m}=$ effect of cow $j$ within square $m ; \tau_{(k)}=$ effect of treatment $k ; \varepsilon_{i j(k) m}=$ random error with mean 0 and variance $\sigma^{2}$. All random effects were considered $\sim \mathrm{N}\left(0, \sigma^{2} \mathrm{e}\right)$. Significant differences were declared at $\mathrm{P}<0.05$ for main effects. Multiple comparisons among treatment means were performed by Tukey's test.

\section{Results}

Dry matter, CP, NDFn, ADFn, lignin, NSCn, fat and $\mathrm{NE}_{\mathrm{L}}$ intakes were not affected by supplements (Table 3).

Average fat intake from supplements and forage was 552 and $435 \mathrm{~g} \mathrm{~d}^{-1}$, respectively. Supplements contributed with

Table 3 - Nutrient intake by dairy cows grazing kikuyu and supplemented with low (palm oil) or high (rice bran or cottonseed) linoleic acid

\begin{tabular}{|c|c|c|c|c|c|}
\hline \multirow{2}{*}{ Feed fraction } & \multicolumn{3}{|c|}{ Supplements } & \multirow{2}{*}{ SEM } & \multirow{2}{*}{ P-valu } \\
\hline & Palm oil & Rice bran & Cottonseed & & \\
\hline \multicolumn{6}{|l|}{ Dry matter } \\
\hline Supplement, $\mathrm{kg} \mathrm{d}^{-1}$ & 5.1 & 5.1 & 4.8 & 0.7 & 0.802 \\
\hline Forage, $\mathrm{kg} \mathrm{d}^{-1}$ & 11.7 & 11.6 & 12.6 & 1.9 & 0.117 \\
\hline \multicolumn{6}{|l|}{ Total } \\
\hline $\mathrm{kg} \mathrm{d}^{-1}$ & 16.8 & 16.6 & 17.4 & 1.9 & 0.238 \\
\hline $\mathrm{g} \mathrm{kg}^{-1}$ of $\mathrm{BW}$ & 29.9 & 29.8 & 30.8 & 3.2 & 0.460 \\
\hline \multicolumn{6}{|l|}{ Crude protein } \\
\hline Supplement, $\mathrm{kg} \mathrm{d}^{-1}$ & 0.8 & 0.9 & 1.0 & 0.2 & 0.417 \\
\hline Forage, $\mathrm{kg} \mathrm{d}^{-1}$ & 2.2 & 2.2 & 2.4 & 0.4 & 0.101 \\
\hline Total, $\mathrm{kg} \mathrm{d}^{-1}$ & 3.0 & 3.1 & 3.4 & 0.4 & 0.171 \\
\hline \multicolumn{6}{|l|}{ Net energy for lactation ${ }^{1}$} \\
\hline Supplement, Mcal d ${ }^{-1}$ & 9.4 & 9.3 & 9.4 & 1.3 & 0.794 \\
\hline Forage, Mcal d ${ }^{-1}$ & 17.3 & 17.1 & 18.5 & 2.6 & 0.098 \\
\hline Total, Mcal d ${ }^{-1}$ & 26.7 & 26.4 & 27.9 & 2.8 & 0.243 \\
\hline \multicolumn{6}{|l|}{ Neutral detergent fiber ${ }^{2}$} \\
\hline Supplement, $\mathrm{kg} \mathrm{d}^{-1}$ & 1.1 & 1.3 & 1.0 & 0.2 & 0.372 \\
\hline Forage, $\mathrm{kg} \mathrm{d}^{-1}$ & 5.6 & 5.5 & 6.0 & 0.9 & 0.145 \\
\hline \multicolumn{6}{|l|}{ Total } \\
\hline $\mathrm{kg} \mathrm{d}^{-1}$ & 6.7 & 6.8 & 7.0 & 0.9 & 0.200 \\
\hline $\mathrm{g} \mathrm{kg}^{-1}$ of BW & 11.9 & 12.1 & 12.3 & 1.5 & 0.417 \\
\hline \multicolumn{6}{|l|}{ Acid detergent fiber ${ }^{2}$} \\
\hline Supplement, $\mathrm{kg} \mathrm{d}^{-1}$ & 1.0 & 0.8 & 0.9 & 0.1 & 0.265 \\
\hline Forage, $\mathrm{kg} \mathrm{d}^{-1}$ & 3.2 & 3.1 & 3.4 & 0.5 & 0.176 \\
\hline Total, $\mathrm{kg} \mathrm{d}^{-1}$ & 4.2 & 3.9 & 4.3 & 0.5 & 0.236 \\
\hline \multicolumn{6}{|l|}{ Lignin } \\
\hline Supplement, $\mathrm{g} \mathrm{d}^{-1}$ & 501 & 463 & 463 & 68 & 0.766 \\
\hline Forage, $\mathrm{g} \mathrm{d}^{-1}$ & 286 & 282 & 306 & 45 & 0.137 \\
\hline Total, $\mathrm{g} \mathrm{d}^{-1}$ & 787 & 745 & 769 & 80 & 0.925 \\
\hline \multicolumn{6}{|c|}{ Non-structural carbohydrates ${ }^{2}$} \\
\hline Supplement, $\mathrm{kg} \mathrm{d}^{-1}$ & 2.1 & 1.9 & 1.8 & 0.3 & 0.688 \\
\hline Forage, $\mathrm{kg} \mathrm{d}^{-1}$ & 2.2 & 2.1 & 2.3 & 0.3 & 0.120 \\
\hline Total, $\mathrm{kg} \mathrm{d}^{-1}$ & 4.2 & 4.1 & 4.1 & 0.4 & 0.546 \\
\hline \multicolumn{6}{|l|}{ Fat } \\
\hline Supplement, $\mathrm{g} \mathrm{d}^{-1}$ & 590 & 522 & 545 & 80 & 0.670 \\
\hline Forage, $\mathrm{g} \mathrm{d}^{-1}$ & 430 & 417 & 459 & 69 & 0.593 \\
\hline Total, $\mathrm{g} \mathrm{d}^{-1}$ & 1021 & 939 & 1003 & 97 & 0.299 \\
\hline
\end{tabular}

${ }^{1}$ Net energy for lactation at the production level of intake (NRC, 2001).

${ }^{2}$ Adjusted by N (NRC, 2001). 
$559 \mathrm{~g}$ of fat $\mathrm{kg}^{-1}$ of total fat intake and $296 \mathrm{~g}$ of $\mathrm{DM} \mathrm{kg}^{-1}$ of total DMI. As compared with $\mathrm{C}, \mathrm{LI}+\mathrm{LN}$ intakes were higher when cows were fed diets $\mathrm{RB}$ or $\mathrm{CS}(\mathrm{P}<0.05)$ mainly due to supplementation because LI and LN intakes from forage were similar among the three diets (Table 4).

The production of milk from cows fed diet CS was lower than that of cows fed diets $\mathrm{RB}$ or $\mathrm{C}(\mathrm{P}<0.05)$. Total milk solids, $\mathrm{CP}$, ash and lactose concentrations were similar in the three treatments. When compared with cows fed diet $\mathrm{RB}$, milk fat concentration was higher for cows fed CS, but similar when fed diet $\mathrm{C}(\mathrm{P}<0.05$; Table 5).

Compared with $\mathrm{CS}$ or $\mathrm{C}$ treatments, the production of milk total solids was higher for cows fed the $\mathrm{RB} \operatorname{diet}(\mathrm{P}<0.05)$ due to a higher lactose and ash production $(\mathrm{P}<0.05)$, since fat and protein production were similar among treatments. Compared with treatments $\mathrm{C}$ and $\mathrm{CS}$, cows fed the RB diet

Table 4 - Linoleic and linolenic acids intake by dairy cows grazing kikuyu and supplemented with low (palm oil) or high (rice bran or cottonseed) linoleic acid

\begin{tabular}{|c|c|c|c|c|c|}
\hline & \multicolumn{3}{|c|}{ Supplement $^{1}$} & \multirow{2}{*}{ SEM } & \multirow{2}{*}{ P-value } \\
\hline & Palm oil & Rice bran & Cottonseed & & \\
\hline \multicolumn{6}{|l|}{ Intake, $\mathrm{g} \mathrm{d}^{-1}$} \\
\hline Supplement & $80 \mathrm{a}$ & $148 b$ & $176 \mathrm{~b}$ & 26 & 0.001 \\
\hline Forage & 32 & 32 & 35 & 5 & 0.563 \\
\hline Total & $113 a$ & $179 b$ & $211 b$ & 24 & 0.001 \\
\hline \multicolumn{6}{|l|}{ Linolenic acid } \\
\hline Forage & 118 & 115 & 126 & 19 & 0.580 \\
\hline Total & 123 & 121 & 132 & 19 & 0.619 \\
\hline \multicolumn{6}{|c|}{ Linoleic + linolenic acids } \\
\hline Supplement & $85 \mathrm{a}$ & $154 \mathrm{~b}$ & $181 \mathrm{~b}$ & 25 & 0.002 \\
\hline Forage & 150 & 146 & 161 & 25 & 0.577 \\
\hline Total & $235 \mathrm{a}$ & $300 \mathrm{~b}$ & $343 b$ & 37 & 0.003 \\
\hline \multicolumn{6}{|l|}{ Linoleic acid } \\
\hline \multicolumn{6}{|l|}{ Linolenic acid } \\
\hline Supplement & $41 \mathrm{a}$ & $55 \mathrm{~b}$ & $45 \mathrm{ab}$ & 7 & 0.039 \\
\hline Forage & $959 \mathrm{a}$ & $945 b$ & $955 \mathrm{ab}$ & 7 & 0.039 \\
\hline \multicolumn{6}{|c|}{ Linoleic + linolenic acids } \\
\hline Supplement & $326 a$ & $463 b$ & $486 \mathrm{~b}$ & 53 & 0.004 \\
\hline Forage & $674 a$ & $537 \mathrm{~b}$ & $514 \mathrm{~b}$ & 53 & 0.004 \\
\hline
\end{tabular}

${ }^{1}$ Means in the same row, followed by different letters are different according to Tukey's test $(\mathrm{P}<0.05)$.

${ }^{2}$ Fatty acid intake from supplement or forage $\mathrm{g} \mathrm{kg}^{-1}$ of total FA intake.

Table 5 - Milk composition and milk yield of dairy cows grazing kikuyu and supplemented with low (palm oil) or high (rice bran or cottonseed) linoleic acid

\begin{tabular}{|c|c|c|c|c|c|}
\hline & \multicolumn{3}{|c|}{ Supplement ${ }^{1}$} & \multirow{2}{*}{ SEM } & \multirow{2}{*}{ P-value } \\
\hline & Palm oil & Rice bran & Cottonseed & & \\
\hline \multicolumn{6}{|c|}{ Milk composition, $\mathrm{g} \mathrm{kg}^{-1}$ as fed } \\
\hline Protein & 29.4 & 28.1 & 29.0 & 1.6 & 0.419 \\
\hline Fat & $33.8 \mathrm{ab}$ & $32.3 \mathrm{a}$ & $36.0 \mathrm{~b}$ & 1.5 & 0.013 \\
\hline Ash & 7.7 & 7.5 & 7.4 & 0.3 & 0.248 \\
\hline Rumenic acid & $0.38 \mathrm{~b}$ & $0.46 \mathrm{a}$ & $0.36 \mathrm{~b}$ & 0.04 & 0.012 \\
\hline Milk yield, $\mathrm{kg} \mathrm{d}^{-1}$ & $21.2 \mathrm{a}$ & $22.0 \mathrm{a}$ & $20.2 b$ & 0.6 & 0.009 \\
\hline \multicolumn{6}{|c|}{ Milk fraction production, $\mathrm{g} \mathrm{d}^{-1}$} \\
\hline Total solids & $2557 \mathrm{ab}$ & $2576 \mathrm{a}$ & $2401 b$ & 103 & 0.048 \\
\hline Protein & 615 & 605 & 580 & 29 & 0.175 \\
\hline Fat & 713 & 702 & 725 & 45 & 0.695 \\
\hline
\end{tabular}

${ }^{1}$ Means in the same row, followed by different letters are different according to Tukey's test $(\mathrm{P}<0.05)$. 
Table 6 - Milk fatty acid (FA) profile of dairy cows grazing kikuyu and supplemented with low (palm oil) or high (rice bran or cottonseed) linoleic acid

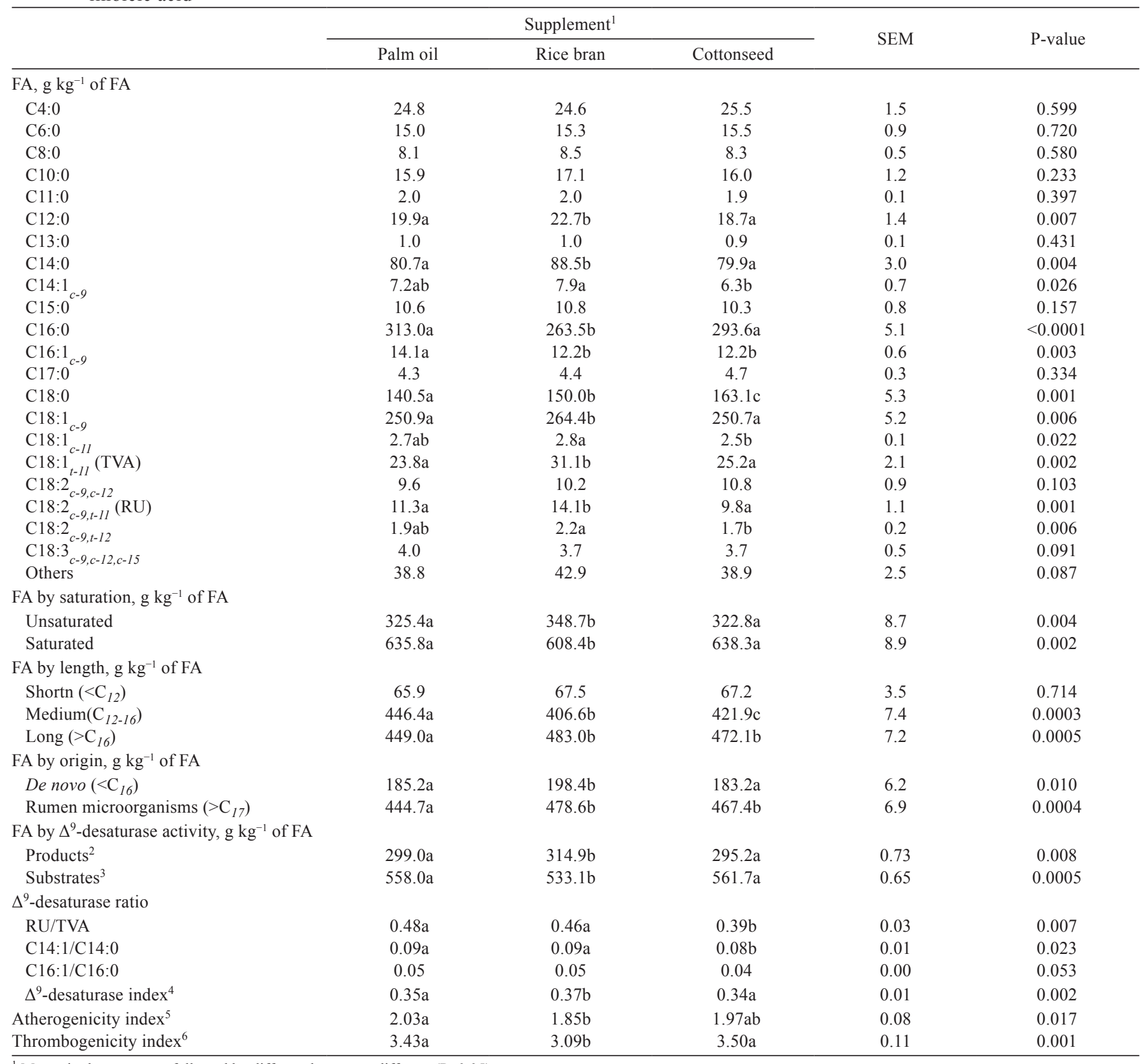

${ }^{1}$ Means in the same row followed by different letters are different $(\mathrm{P}<0.05)$

${ }^{2} \mathrm{C} 14: 1_{\mathrm{c}-9}+\mathrm{C} 16: 1_{\mathrm{c}-9}+\mathrm{C} 18: 1_{\mathrm{c}-9}+\mathrm{C} 18: 2_{\mathrm{c}-9, \mathrm{t}-11}$.

${ }^{3} \mathrm{C} 14: 0+\mathrm{C} 16: 0+\mathrm{C} 18: 0+\mathrm{C} 18: 1_{\mathrm{t}-11}$.

${ }^{4}$ Products $\Delta^{9}$-desaturase $\times\left(\text { Substrates } \Delta^{9} \text {-desaturase }+ \text { Products } \Delta^{9} \text {-desaturase }\right)^{-1}$ (Gagliostro et al., 2006).

${ }^{5}(\mathrm{C} 12: 0+4 \mathrm{C} 14: 0+\mathrm{C} 16: 0) \times(\text { FA unsaturated })^{-1}$ (Ulbricht and Southgate, 1991).

${ }^{6}(\mathrm{C} 14: 0+\mathrm{C} 16: 0+\mathrm{C} 18: 0) \times[0.5 \mathrm{MUFA}+0.5 \omega-6+3 \omega-3+(\omega-3 / \omega-6)]^{-1}$ (Ulbricht and Southgate, 1991).

Table 7 - Body weight, body condition score and $\mathrm{pH}$ and ammonia in rumen fluid of dairy cows grazing kikuyu and supplemented with low (palm oil) or high (rice bran or cottonseed) linoleic acid

\begin{tabular}{|c|c|c|c|c|c|}
\hline & \multicolumn{3}{|c|}{ Supplement } & \multirow{2}{*}{ SEM } & \multirow{2}{*}{ P-value } \\
\hline & Palm oil & Rice bran & Cottonseed & & \\
\hline Body weight, kg & 559 & 561 & 562 & 10 & 0.839 \\
\hline Body condition score & 3.5 & 3.5 & 3.7 & 0.2 & 0.414 \\
\hline \multicolumn{6}{|l|}{ Rumen fluid } \\
\hline $\mathrm{pH}$ & 6.6 & 6.6 & 6.9 & 0.3 & 0.190 \\
\hline $\mathrm{N}-\mathrm{NH}_{3}, \mathrm{mg} \mathrm{dL}^{-1}$ & 13.7 & 14.5 & 13.8 & 1.6 & 0.623 \\
\hline
\end{tabular}


had higher milk concentrations of TVA $(\mathrm{P}<0.05)$ and RU $(\mathrm{P}<0.05)$ acids, and consequently a higher production $\left(\mathrm{g} \mathrm{d}^{-1}\right)$ of these FA ( $\mathrm{P}<0.05$; Table 5).

Cows receiving the $\mathrm{RB}$ diet had higher proportion of unsaturated FA in milk $(\mathrm{P}<0.05)$. Concentrations of milk long- $\left(>\mathrm{C}_{16}\right)$ and medium-chain $\left(\mathrm{C}_{12}-\mathrm{C}_{16}\right)$ FA were affected by the addition of supplements $(\mathrm{P}<0.05)$, but the concentration of short-chain $\mathrm{FA}\left(<\mathrm{C}_{12}\right)$ was not. Comparing milk from cows fed CS, medium chain FA concentration was higher for cows fed diet $\mathrm{C}$ and lower for those fed diet RB $(\mathrm{P}<0.05)$. Milk long-chain FA concentration was lower for cows in treatment $C$, compared with cows in treatments $\mathrm{RB}$ or $\mathrm{CS}(\mathrm{P}<0.05$; Table 6$)$.

Concentrations of C4:0, C6:0, C8:0, C10:0, C11:0, $\mathrm{C} 13: 0, \mathrm{C} 15: 0, \mathrm{C} 17: 0, \mathrm{C} 18: 2_{c-9, c-12}$ and $\mathrm{C} 18: 3_{c-9, c-12, c-15}$ in milk fat were similar among treatments. Compared with treatments $\mathrm{C}$ and $\mathrm{CS}$, cows consuming the RB diet had a higher milk concentration of C12:0, C14:0, C18:1 ${ }_{c-9}$, TVA and RU, while concentration of $\mathrm{C} 16: 0$ was lower $(\mathrm{P}<0.05)$. Cows consuming the $\mathrm{CS}$ diet had a higher milk concentration of $\mathrm{C} 14: 1_{c-9}, \mathrm{C} 18: 1_{c-11}$ and $\mathrm{C} 18: 2_{c-9, t-12}$ than cows consuming the $\mathrm{RB}$ diet $(\mathrm{P}<0.05)$. Milk from cows fed diets RB or CS had a lower concentration of $16: 1_{c-9}$ than milk from cows consuming the $\mathrm{C}$ diet $(\mathrm{P}<0.05)$. Compared with the milk from cows fed RB, milk C18:0 concentration was higher for cows in treatment CS and lower for those in treatment $\mathrm{C}$ $(\mathrm{P}<0.05$; Table 6).

Concentration of preformed FA $\left(>\mathrm{C}_{17}\right)$ in milk fat was lower for cows fed diet $\mathrm{C}$ compared with cows fed diets $\mathrm{RB}$ or CS $(\mathrm{P}<0.05)$, and there was a higher concentration of de novo synthesized $\mathrm{FA}\left(<\mathrm{C}_{16}\right)$ in the milk from cows in the RB treatment $(\mathrm{P}<0.05$; Table 6$)$.

Milk RU/TVA, C14:1/C14:0 and C16:1/C16:0 ratios were lower in the milk from cows receiving the RB diet, compared with cows in the CS or $\mathrm{C}$ treatments $(\mathrm{P}<0.05)$. The index of $\Delta^{9}$-desaturase and the concentrations of this enzyme products were the highest for milk from cows in treatment $\mathrm{RB}$, but the concentrations of their substrates were the lowest $(\mathrm{P}<0.05)$. Compared with the milk from cows fed diet $\mathrm{C}$, milk fat of cows in treatment RB had a higher AI $(\mathrm{P}<0.05)$. The thrombogenicity index was the lowest for cows under the RB treatment $(\mathrm{P}<0.05$; Table 6).

Live weight, $\mathrm{BSC}$ and ruminal fluid $\left(\mathrm{pH}\right.$ and $\left.\mathrm{N}-\mathrm{NH}_{3}\right)$ were not affected by the type of supplement (Table 7).

\section{Discussion}

The effects of offering supplements containing palm oil, cottonseed or rice bran to grazing dairy cows on their milk FA profile were studied. Three supplements were prepared with palm oil, cottonseed or rice bran, having a similar nutritional composition and a similar amount of fat. The concentration of LI was similar for supplements containing $\mathrm{CS}$ or RB, and lower for the supplement containing palm oil.

It has been suggested that an increase in dietary fat of more than 80 to $90 \mathrm{~g} \mathrm{~kg}^{-1}$ of DM decreases DMI (Palmquist and Jenkins, 1980; Schauff and Clark, 1992). This effect is larger with a higher concentration of unsaturated FA in the supplement (Firkins and Eastridge, 1994; Bremmer et al., 1998). Other studies suggest that increasing fat level in the diet of grazing cows does not affect DMI (Bargo et al., 2003; Schroeder et al., 2004). In our experiment, the total dietary fat concentration was $58 \mathrm{~g} \mathrm{~kg}^{-1}$ of $\mathrm{DM}$, in which the supplements contributed with nearly $55.8 \%$. The intake of DM, CP, fat and fiber was similar among the diets, regardless of fat level and the concentration of unsaturated FA. Therefore, it can be suggested that the major effects of feeding supplements are mainly associated with the FA profile and source.

Comparing milk from cows receiving supplements containing palm oil or rice bran, the supplement containing cottonseed resulted in a lower yield of milk, total solids and a higher milk fat concentration. A higher milk fat concentration and a lower milk production in cows consuming the supplement containing cottonseed resulted in a fat production similar to that of the other two diets. Some researchers did not find any cottonseed effect on milk fat concentration or on milk fat production (Bitman et al., 1996), while others report an increase (Belibasakis and Tsirgogianni, 1995; Harrison et al., 1995) or a decrease (Wilks et al., 1991; Smith et al., 1993) in these parameters.

Differences in the yield of milk and total solids by feeding supplements containing cottonseed or rice bran cannot be explained by the differences in LI intake, since it was similar for treatments CS and RB. Differences in milk production have been associated with energy intake (van Knegsel et al., 2007). However, in our experiment, digestible energy intake calculated using markers, and net energy intake derived from NRC equations (NRC, 2001) were not different among treatments. A lower milk production with similar energy intakes by cows consuming the CS diet implies a lower efficiency in their use of digestible energy.

Cottonseed contains toxic compounds such as gossypol (Zhang et al., 2007) but it has been suggested that gossypol is modified by ruminal microorganisms (Reiser and $\mathrm{Fu}, 1962$ ). However, there is evidence showing that part of gossypol escapes ruminal fermentation (Mena et al., 2004) and can affect animal health and performance (Risco et al., 2002). Effects of gossypol can lead to low hemoglobin and hematocrit levels (Velasquez-Pereira et al., 1999), osmotic 
fragility of erythrocyte, decrease in cell antioxidant power (Risco et al., 2002), productive performance (Santos et al., 2003; Villaseñor et al., 2008), milk production and breathing rate and finally death (Lindsey et al., 1980).

Some authors suggest that cottonseed can be used in milking cows at up to $3-4 \mathrm{~kg} \mathrm{cow}^{-1} \mathrm{~d}^{-1}$ or $150 \mathrm{~g} \mathrm{~kg}^{-1}$ of their diet without negative effects (Coppock et al., 1987; Arieli, 1998; Zhang et al., 2007), although gossypol concentrations are different depending on the cotton varieties (Zhang et al., 2007). Gossypol intake was not determined in our experiment, but energy efficiency utilization was reduced in cows receiving supplement CS, though cottonseed intake $\left(1.5 \mathrm{~kg} \mathrm{cow}^{-1} \mathrm{~d}^{-1}\right)$ was lower than the maximum level recommended in the literature.

Most authors suggest that increasing LI intake will increase milk TVA and RU (Dewhurst et al., 2006; AbuGhazaleh et al., 2007; Bu et al., 2007; Huang et al., 2008; Bouattour et al., 2008; Hervás et al., 2008; Bharathan et al., 2008). Linoleic and $\mathrm{LN}$ acids intake has been associated with milk TVA and RU (Loor et al., 2005a; AbuGhazaleh et al., 2007; Bu et al., 2007; Huang et al., 2008). In our study, LI intake was similar for cows fed RB or CS and near twice as much as those on diet C. Linolenic acid was not affected by supplementation and came mainly from forage, suggesting that differences in milk concentrations of TVA and RU were mainly explained by LI intake and source.

In our study, higher intakes of LI increased TVA and RU concentration in milk lipids for $\mathrm{RB}$, but not for diet CS. Differences between diets CS and RB are not easy to explain since intakes of precursors of these two FA in milk were similar. Some authors suggest that whole seeds may produce a lower concentration of TVA and RU in milk lipid than processed seed, due to a lower ruminal availability of unsaturated FA in whole seeds, where FA are protected from ruminal biohydrogenation, resulting in a higher concentration of milk unsaturated FA (Dhiman et al., 2000; Khanal et al., 2005; Paradis et al., 2008). However, CS had lower concentrations of LI and LN acids and higher concentrations of stearic acid in milk lipids than RB, suggesting a more extensive biohydrogenation in the CS diet. Therefore, a low concentration of milk TVA and RU for cows fed the CS diet compared with those under the RB diet could not be explained by a low ruminal availability of LI, but rather by a more extensive biohydrogenation of LI in the CS diet. Pires et al. (1997) found a higher ruminal biohydrogenation of LI to C18:0 and a lower milk concentration of $\mathrm{C} 18: 2$ when unprocessed cottonseed was fed compared with heat-treated and physically-processed cottonseed. Harvatine et al. (2002) found that when cottonseed is included in the diet of dairy cows ( 0 to $150 \mathrm{~g} \mathrm{~kg}^{-1}$ of DM) there is a linear increase in ruminal biohydrogenation of LI and outflow of C18:0 to the intestine. In our study we observed higher milk C18:0 concentrations in cows receiving the CS diet, compared with cows ingesting diets $\mathrm{C}$ or $\mathrm{RB}$. This was possibly due to the fact that CS has a lower passage rate, and consequently remains longer in the rumen (Pires et al., 1997). Furthermore, RB and CS have similar concentrations of LI, but CS has a lower passage rate, suggesting RB will be a better alternative to increase milk TVA and RU.

In addition to increases in the concentration of TVA and RU in milk, other changes occurred in the milk FA profile, due to the dietary supplements in our experiment. When compared with cows fed diets C or CS, milk lipids of cows consuming RB supplement had higher concentrations of C12:0 and C14:0, and lower concentration of C16:0. Milk $\mathrm{C} 12: 0$ and $\mathrm{C} 14: 0$ are synthesized in the mammary gland (Garnsworthy et al., 2006), C14:0 being the main product of this process (Barber et al., 1997). The de novo synthesis of FA (less than $16 \mathrm{C}$ ) is predominant when cows are in a positive energy balance and do not depend on body energy reserves (Palmquist et al., 1993), while the concentration of preformed FA (long chain) in milk fat will be lower (Garnsworthy et al., 2006). In our study, cows receiving supplement RB had higher concentration of preformed FA in milk fat, suggesting a better energy balance than cows receiving supplements $\mathrm{C}$ or CS, regardless of similar energy intakes among diets, and a higher milk yield for the RB diet. Moreover, intake of C12:0 and C14:0 was higher for the $\mathrm{C}$ diet $(\mathrm{P}<0.05$, data not shown) than for diets $\mathrm{RB}$ or CS. Therefore, differences in intake do not explain a higher concentration of these FA in the milk from cows receiving a supplement containing RB.

Variations in the ruminal microbial population could be related to change in FA profile in milk (AbuGhazaleh et al., 2003; AlZahal et al., 2008). Lipids present in ruminal microorganisms can be generated by the de novo synthesis (Schmidely et al., 2008; Váradyová et al., 2008) and bacteria have a higher concentration of these FA than protozoa (Or-Rashid et al., 2007). An increased concentration of milk C12:0 and C14:0 for the RB diet could be due to a decrease in ruminal population of protozoa when cows were fed the RB diet. However, protozoa populations were not measured in our study, and factors such as increasing levels of dietary starch or lower ruminal pH (Goad et al., 1998; Khafipour et al., 2009; Hook et al., 2011), which have been related to ruminal population of protozoa, were similar among diets. Some researchers have reported that feeding oil decreases the population of protozoa in the rumen, depending on the type and availability of FA (Toral et al., 2009; Reveneau et al., 2012). 
Milk concentration of $\mathrm{C} 16: 0$ for cows fed the RB diet was lower than for those fed diets CS or C. Milk C16:0 can originate from diet, de novo synthesis, adipose tissue mobilization or ruminal microorganisms (Linzell and Peaker, 1971; Barber et al., 1997). Compared with treatment C, the lower milk concentration of $\mathrm{C} 16: 0$ for cows fed diet RB could be explained by a lower C16:0 intake. However, differences in milk C16:0 concentration between cows fed diets RB or CS could not be explained by differences in the C16:0 intake, because the two diets had similar levels and intake of C16:0. Additionally, milk concentration of C16:0 was similar for diets $\mathrm{C}$ and $\mathrm{CS}$. A lower concentration of milk C16:0 for cows fed the RB diet did not explain a decrease in the de novo synthesis, because milk concentration of $\mathrm{C}_{12}$ and $\mathrm{C}_{14}$ increased with diet RB. The lower milk concentration of $\mathrm{C} 16: 0$ also could not be explained by a lower adipose tissue lipid mobilization, since preformed FA concentration in milk was higher for cows fed diet RB. A lower C16:0 concentration in rumen microorganisms could explain a decrease in this FA in milk for cows on the RB treatment since it is one of its predominant FA (Or-Rashid et al., 2007; Váradyová et al., 2008), and it is produced by the de novo synthesis by ruminal microorganisms (Williams, 1986).

Changes in microbial populations by supplementation with different oils result in changes in the FA composition of rumen contents (Toral et al., 2012). Approximately 75 to $150 \mathrm{~g} \mathrm{~kg}^{-1}$ of lipids in the rumen digesta (Or-Rashid et al., 2007) and $750 \mathrm{~g} \mathrm{~kg}^{-1}$ of FA in rumen microorganisms (Jenkins et al., 2008) come from protozoa. Ruminal protozoa are an important source of lipids for the host animal (Or-Rashid et al., 2007), and have a higher concentration of C16:0 than bacteria (Váradyová et al., 2008). Fat decreases ruminal protozoa population depending on their source and FA composition and availability (Reveneau et al., 2012), and supplementation with sunflower oil alone or with marine algae in diets for sheep decreases the concentration of C16:0 in rumen content (Toral et al., 2009). Therefore, it is likely that RB supplementation decreased ruminal protozoa explaining the lower concentration of milk C16:0 for cows fed diet RB.

Compared with cows fed diet $\mathrm{C}$, milk from cows fed diet $\mathrm{RB}$ has lower AI $(\mathrm{P}<0.05)$ and $\mathrm{TI}(\mathrm{P}<0.01)$, which could be explained by a low milk concentration of $\mathrm{C} 16: 0$ and a high milk concentration of unsaturated FA. A higher concentration of unsaturated FA can be beneficial for human health (Jacobs et al., 2011). Most of coronary diseases are the result of blood vessel obstruction by atheroma or thrombus (Ulbricht and Southgate, 1991). Therefore, the use of milk with low AI and TI could be an alternative for health markets.
The enzyme $\Delta^{9}$-desaturase is present in the mammary gland and its activity was calculated by the ratio of milk concentration of an unsaturated FA over milk concentration of a saturated FA of the same number of $\mathrm{C}$. The ratio between products over substrates of $\Delta^{9}$-desaturase can be an estimate of its activity (Jacobs et al., 2011) or its concentration (Feng et al., 2004).

It has been suggested that the presence of the ciclopropenes malvalic and sterculic acids in cottonseed (Coppock et al., 1987) inhibits the $\Delta^{9}$-desaturase activity (Allen et al., 1967). However, these acids are biohydrogenated in the rumen, losing their inhibitory effect on $\Delta^{9}$-desaturase (Corl et al., 2001). Some cyclopropenes escape ruminal biohydrogenation (Yang et al., 1999) and therefore can inhibit $\Delta^{9}$-desaturase (Hawkins et al., 1985).

Although we did not determine the concentrations of sterculic and malvalic acids in the cottonseed we used, our results suggest that these FA inactivated $\Delta^{9}$-desaturase. C14:0 is mainly synthesized de novo by the mammary gland and C14:1 originates from the desaturation of C14:0 by $\Delta^{9}$-desaturase (Corl et al., 2001). In our experiment, the ratio between milk concentrations of C14:1/C14:0 was lower for cows fed CS than for cows fed the other two diets, suggesting that the inhibition of $\Delta^{9}$-desaturase was caused by cottonseed. This lower $\Delta^{9}$-desaturase activity may explain the higher concentration of $\mathrm{C} 18: 0$, as well as lower RU in milk fat from cows which consumed the CS diet, as was the case in our trial.

\section{Conclusions}

When cows are grazing kikuyu and fed a supplement containing rice bran instead of a supplement containing palm oil or cottonseed their milk concentration of unsaturated fatty acids, trans-vaccenic and rumenic acids increase, and their milk atherogenicity and thrombogenicity indexes decrease. Rice bran is a better source of linoleic acid to modify the fatty acid profile of milk than cottonseed, since the former produces a higher concentration of transvaccenic acid, rumenic acid and unsaturated fatty acids, and presents lower atherogenicity and thrombogenicity indexes, resulting in a kind of milk beneficial for human health.

\section{Acknowledgements}

The authors thank Ministerio de Agricultura y Desarrollo Rural for its economic support; and Laboratorio de Nutrición Animal de la Facultad de Medicina Veterinaria y de Zootecnia and Centro Agropecuario Marengo, Universidad Nacional de Colombia, Sede Bogotá. 


\section{References}

AbuGhazaleh, A. A.; Felton, D. O. and Ibrahim, S. A. 2007. Milk conjugated linoleic acid response to fish oil and sunflower oil supplementation to dairy cows managed under two feeding systems. Journal of Dairy Science 90:4763-4769.

AbuGhazaleh, A. A.; Schingoethe, D. J.; Hippen, A. R. and Kalscheur, K. F. 2003. Milk conjugated linoleic acid response to fish oil supplementation of diets differing in fatty acid profiles. Journal of Dairy Science 86:944-953.

Aguilar, O. X.; Moreno, B. M.; Pabón, M. L. and Carulla, J. E. 2009. Efecto del consumo de kikuyo (Pennisetum clandestinum) o raigrás (Lolium hibridum) sobre la concentración de ácido linoléico conjugado y el perfil de ácidos grasos de la grasa láctea. Livestock Research for Rural Development 21:49. Available at: $<$ http://www.lrrd.org/lrrd21/4/agui21049.htm> Accessed on: Nov. 17, 2011.

Allen, E.; Johnson, A.; Fogerty, A.; Pearson, J. and Shenstone, F. 1967. Inhibition by cyclopropene fatty acids of the desaturation of stearic acid in hen liver. Lipids 2:419-423.

Allen, M. S. 2000. Effects of diet on short-term regulation of feed intake by lactating dairy cattle. Journal of Dairy Science 83:1598-1624.

AlZahal, O.; Odongo, N. E.; Mutsvangwa, T.; Or-Rashid, M. M.; Duffield, T. F.; Bagg, R.; Dick, P.; Vessie, G. and McBride, B. W. 2008. Effects of monensin and dietary soybean oil on milk fat percentage and milk fatty acid profile in lactating dairy cows. Journal of Dairy Science 91:1166-1174.

AOAC - Association Official to Analytical Chemistry. 2010. Official methods of analysis of AOAC International. 18th ed. AOAC International, Maryland.

Arieli, A. 1998. Whole cottonseed in dairy cattle feeding: a review. Animal Feed Science and Technology 72:97-110.

Barber, M. C.; Clegg, R. A.; Travers, M. T. and Vernon, R. G. 1997. Lipid metabolism in the lactating mammary gland. Biochimica et Biophysca Acta 1347:101-126.

Bargo, F.; Muller, L. D.; Kolver, E. S. and Delahoy, J. E. 2003. Invited review: Production and digestion of supplemented dairy cows on pasture. Journal of Dairy Science 86:1-42.

Belibasakis, N. G. and Tsirgogianni, D. 1995. Effects of whole cottonseeds on milk yield, milk composition, and blood components of dairy cows in hot weather. Animal Feed Science and Technology 52:227-235.

Bharathan, M.; Schingoethe, D. J.; Hippen, A. R.; Kalscheur, K. F.; Gibson, M. L. and Karges, K. 2008. Conjugated linoleic acid increases in milk from cows fed condensed corn distillers solubles and fish oil. Journal of Dairy Science 91:2796-2807.

Bitman, J.; Wood, D. L.; Miller, R. H.; Tyrrell, H. F.; Reynolds, C. K. and Baxter, H. D. 1996. Comparison of milk and blood lipids in jersey and holstein cows fed total mixed rations with or without whole cottonseed. Journal of Dairy Science 79:1596-1602.

Bouattour, M. A.; Casals, R.; Albanell, E.; Such, X. and Caja, G. 2008. Feeding soybean oil to dairy goats increases conjugated linoleic acid in milk. Journal of Dairy Science 91:2399-2407.

Bremmer, D. R.; Ruppert, L. D.; Clark, J. H. and Drackley, J. K. 1998. Effects of chain length and unsaturation of fatty acid mixtures infused into the abomasum of lactating dairy cows. Journal of Dairy Science 81:176-188.

Bu, D. P.; Wang, J. Q.; Dhiman, T. R. and Liu, S. J. 2007. Effectiveness of oils rich in linoleic and linolenic acids to enhance conjugated linoleic acid in milk from dairy cows. Journal of Dairy Science 90:998-1007.

Cook, C. W. 1964. Symposium on nutrition of forages and pastures: collecting forage samples representative of ingested material of grazing animals for nutritional studies. Journal of Animal Science 23:265-270.

Coppock, C. E.; Lanham, J. K. and Horner, J. L. 1987. A review of the nutritive value and utilization of whole cottonseed, cottonseed meal and associated by-products by dairy cattle. Animal Feed Science and Technology 18:89-129.
Corl, B. A.; Baumgard, L. H.; Dwyer, D. A.; Griinari, J. M.; Phillips, B. S. and Bauman, D. E. 2001. The role of $\Delta^{9}$-desaturase in the production of cis-9, trans-11 CLA. The Journal of Nutritional Biochemistry 12:622-630.

Correa, H. J.; Pabón, M. L. and Carulla, J. E. 2008. Valor nutricional del pasto kikuyo (Pennisetum clandestinum Hoechst Ex Chiov.) para la producción de leche en Colombia (Una revisión): I Composición química y digestibilidad ruminal y posruminal. Livestock Research for Rural Development 20:59. Available at: $<$ http://www.lrrd.org/lrrd20/4/corra20059.htm> Accessed on: Nov. 18, 2011

Correa, H. J.; Pabón, M. L. and Carulla, J. E. 2009. Estimación del consumo de materia seca en vacas Holstein bajo pastoreo en el trópico alto de Antioquia. Livestock Research for Rural Development 21:59. Available at: <http://www.lrrd.org/lrrd21/4/corr21059.htm> Accessed on: Nov. 18, 2011.

de Campos, R. M. L.; Hierro, E.; Ordóñez, J. A.; Bertol, T. M.; Terra, N. N. and de la Hoz, L. 2007. Fatty acid and volatile compounds from salami manufactured with yerba mate (Ilex paraguariensis) extract and pork back fat and meat from pigs fed on diets with partial replacement of maize with rice bran. Food Chemistry 103:1159-1167.

Dewhurst, R. J.; Shingfield, K. J.; Lee, M. R. F. and Scollan, N. D. 2006. Increasing the concentrations of beneficial polyunsaturated fatty acids in milk produced by dairy cows in high-forage systems. Animal Feed Science and Technology 131:168-206.

Dhiman, T. R.; Helmink, E. D.; McMahon, D. J.; Fife, R. L. and Pariza, M. W. 1999. Conjugated linoleic acid content of milk and cheese from cows fed extruded oilseeds. Journal of Dairy Science 82:412-419.

Dhiman, T. R.; Satter, L. D.; Pariza, M. W.; Galli, M. P.; Albright, K. and Tolosa, M. X. 2000. Conjugated linoleic acid (CLA) content of milk from cows offered diets rich in linoleic and linolenic acid. Journal of Dairy Science 83:1016-1027.

Díaz-González, G.; Gutiérrez, R.; Pérez, N.; Vega, S.; León, S.; González, M.; Prado, G.; Urbán, G.; Ramírez, A. and Pinto, M. 2002. Detección de adulteraciones en la grasa de leche pasteurizada mexicana. Revista de Salud Animal 24:54-59.

Edmonson, A. J.; Lean, I. J.; Weaver, L. D.; Farver, T. and Webster, G. 1989. A body condition scoring chart for Holstein dairy cows. Journal of Dairy Science 72:68-78.

Feng, S.; Lock, A. L. and Garnsworthy, P. C. 2004. Technical note: a rapid lipid separation method for determining fatty acid composition of milk. Journal of Dairy Science 87:3785-3788.

Firkins, J. L. and Eastridge, M. L. 1994. Assessment of the effects of iodine value on fatty acid digestibility, feed intake, and milk production. Journal of Dairy Science 77:2357-2366.

Flowers, G.; Ibrahim, S. A. and Abughazaleh, A. A. 2008. Milk fatty acid composition of grazing dairy cows when supplemented with linseed oil. Journal of Dairy Science 91:722-730.

Folch, J.; Lees, M. and Stanley, G. H. S. 1957. A simple method for the isolation and purification of total lipides from animal tissues. Journal of Biological Chemistry 226:497-509.

Gagliostro, G. A.; Rodríguez, A.; Pellegrini, P.; Gatti, P.; Musset, G.; Castañeda, R. A.; Colombo, D. and Chilliard, Y. 2006. Efectos del suministro de aceite de pescado sólo o en combinación con aceite de girasol sobre las concentraciones de ácido linoleico conjugado (CLA) y omega 3 (n-3) en leche de cabra. Revista Argentina de Producción Animal 26:71-87.

Garces, R. and Mancha, M. 1993. One-step lipid extraction and fatty acid methyl esters preparation from fresh plant tissues. Analytical Biochemistry 211:139-143.

Garnsworthy, P. C.; Masson, L. L.; Lock, A. L. and Mottram, T. T. 2006. Variation of milk citrate with stage of lactation and de novo fatty acid synthesis in dairy cows. Journal of Dairy Science 89:1604-1612.

Goad, D. W.; Goad, C. L. and Nagaraja, T. G. 1998. Ruminal microbial and fermentative changes associated with experimentally induced subacute acidosis in steers. Journal of Animal Science 76:234-241. 
Harrison, J. H.; Kincaid, R. L.; McNamara, J. P.; Waltner, S.; Loney, K. A.; Riley, R. E. and Cronrath, J. D. 1995. Effect of whole cottonseeds and calcium salts of long-chain fatty acids on performance of lactating dairy cows. Journal of Dairy Science 78:181-193.

Harvatine, D. I.; Firkins, J. L. and Eastridge, M. L. 2002. Whole linted cottonseed as a forage substitute fed with ground or steam-flaked corn: digestibility and performance. Journal of Dairy Science 85:1976-1987.

Hawkins, G. E.; Cummins, K. A.; Silverio, M. and Jilek, J. J. 1985. Physiological effects of whole cottonseed in the diet of lactating dairy cows. Journal of Dairy Science 68:2608-2614.

Hervás, G.; Luna, P.; Mantecón, A. R.; Castañares, N.; de la Fuente, M. A.; Juárez, M. and Frutos, P. 2008. Effect of diet supplementation with sunflower oil on milk production, fatty acid profile and ruminal fermentation in lactating dairy ewes. Journal of Dairy Research 75:399-405.

Holden, L. A.; Muller, L. D. and Fales, S. L. 1994. Estimation of intake in high producing Holstein cows grazing grass pasture. Journal of Dairy Science 77:2332-2340.

Hook, S. E.; Steele, M. A.; Northwood, K. S.; Wright, A. D. G. and McBride, B. W. 2011. Impact of high-concentrate feeding and low ruminal $\mathrm{pH}$ on methanogens and protozoa in the rumen of dairy cows. Microbial Ecology 62:94-105.

Houseknecht, K. L.; Heuvel, J. P. V.; Moya-Camarena, S. Y.; Portocarrero, C. P.; Peck, L. W.; Nickel, K. P. and Belury, M. A. 1998. Dietary conjugated linoleic acid normalizes impaired glucose tolerance in the zucker diabetic fatty $f a / f a$ rat. Biochemical and Biophysical Research Communications 244:678-682.

Huang, Y.; Schoonmaker, J. P.; Bradford, B. J. and Beitz, D. C. 2008. Response of milk fatty acid composition to dietary supplementation of soy oil, conjugated linoleic acid, or both. Journal of Dairy Science 91:260-270.

Huang, Y.; Schoonmaker, J. P.; Oren, S. L.; Trenkle, A. and Beitz, D. C. 2009. Calcium salts of CLA improve availability of dietary CLA. Livestock Science 122:1-7.

Hurley, W. L.; Warner, G. J. and Grummer, R. R. 1987. Changes in triglyceride fatty acid composition of mammary secretions during involution. Journal of Dairy Science 70:2406-2410.

Ip, C.; Banni, S.; Angioni, E.; Carta, G.; McGinley, J.; Thompson, H. J.; Barbano, D. and Bauman, D. 1999. Conjugated linoleic acid-enriched butter fat alters mammary gland morphogenesis and reduces cancer risk in rats. Journal of Nutrition 129:2135-2142.

Jacobs, A. A. A.; van Baal, J.; Smits, M. A.; Taweel, H. Z. H.; Hendriks, W. H.; van Vuuren, A. M. and Dijkstra, J. 2011. Effects of feeding rapeseed oil, soybean oil, or linseed oil on stearoylCoA desaturase expression in the mammary gland of dairy cows. Journal of Dairy Science 94:874-887.

Jenkins, T. C.; Wallace, R. J.; Moate, P. J. and Mosley, E. E. 2008. Board-Invited review: Recent advances in biohydrogenation of unsaturated fatty acids within the rumen microbial ecosystem. Journal of Animal Science 86:397-412.

Jensen, R. G. 2002. The composition of bovine milk lipids: january 1995 to december 2000. Journal of Dairy Science 85:295-350.

Kelly, M. L.; Kolver, E. S.; Bauman, D. E.; Van Amburgh, M. E. and Muller, L. D. 1998. Effect of intake of pasture on concentrations of conjugated linoleic acid in milk of lactating cows. Journal of Dairy Science 81:1630-1636.

Khafipour, E.; Li, S.; Plaizier, J. C. and Krause, D. O. 2009. Rumen microbiome composition determined using two nutritional models of subacute ruminal acidosis. Applied and Environmental Microbiology 75:7115-7124.

Khanal, R. C.; Dhiman, T. R. and Boman, R. L. 2008. Changes in fatty acid composition of milk from lactating dairy cows during transition to and from pasture. Livestock Science 114:164-175.

Khanal, R. C.; Dhiman, T. R.; Ure, A. L.; Brennand, C. P.; Boman, R. L. and McMahon, D. J. 2005. Consumer acceptability of conjugated linoleic acid-enriched milk and cheddar cheese from cows grazing on pasture. Journal of Dairy Science 88:1837-1847.
Khanal, R. C. and Olson, K. C. 2004. Factors affecting conjugated linoleic acid (CLA) content in milk, meat and egg - A review. Pakistan Journal of Nutrition 3:82-98.

Licitra, G.; Hernandez, T. M. and Van Soest, P. J. 1996. Standardization of procedures for nitrogen fractionation of ruminant feeds. Animal Feed Science and Technology 57:347-358.

Lindsey, T. O.; Hawkins, G. E. and Guthrie, L. D. 1980. Physiological responses of lactating cows to gossypol from cottonseed meal rations. Journal of Dairy Science 63:562-573.

Linzell, J. L. and Peaker, M. 1971. Mechanism of milk secretion. Physiological Reviews 51:564-597.

Loor, J. J.; Ferlay, A.; Ollier, A.; Doreau, M. and Chilliard, Y. 2005a. Relationship among trans and conjugated fatty acids and bovine milk fat yield due to dietary concentrate and linseed oil. Journal of Dairy Science 88:726-740.

Loor, J. J.; Ferlay, A.; Ollier, A.; Ueda, K.; Doreau, M. and Chilliard, Y. 2005b. High-concentrate diets and polyunsaturated oils alter trans and conjugated isomers in bovine rumen, blood, and milk. Journal of Dairy Science 88:3986-3999.

Lynch, J. M.; Barbano, D. M. and Fleming, J. R. 2007. Determination of the lactose content of fluid milk by spectrophotometric enzymatic analysis using weight additions and path length adjustment: Collaborative study. Journal of AOAC International 90:196-215.

Mel'uchová, B.; Blasko, J.; Kubinec, R.; Górová, R.; Dubravská, J.; Margetín, M. and Soják, L. 2008. Seasonal variations in fatty acid composition of pasture forage plants and CLA content in ewe milk fat. Small Ruminant Research 78:56-65.

Mena, H.; Santos, J. E. P.; Huber, J. T.; Tarazon, M. and Calhoun, M. C. 2004. The effects of varying gossypol intake from whole cottonseed and cottonseed meal on lactation and blood parameters in lactating dairy cows. Journal of Dairy Science 87:2506-2518.

Muir, J. P. 2002. Hand-Plucked forage yield and quality and seed production from annual and short-lived perennial warm-season legumes fertilized with composted manure. Crop Science 42:897-904.

Munday, J. S.; Thompson, K. G. and James, K. A. C. 1999. Dietary conjugated linoleic acids promote fatty streak formation in the C57BL/6 mouse atherosclerosis model. British Journal of Nutrition 81:251-255.

NRC - National Research Council. 2001. Nutrient requerimients of dairy cattle. 7th ed. National Academy Press, Washington, DC.

Or-Rashid, M. M.; Odongo, N. E. and McBride, B. W. 2007. Fatty acid composition of ruminal bacteria and protozoa, with emphasis on conjugated linoleic acid, vaccenic acid, and odd-chain and branchedchain fatty acids. Journal of Animal Science 85:1228-1234.

Palmquist, D. L.; Beaulieu, A. D. and Barbano, D. M. 1993. Feed and animal factors influencing milk fat composition. Journal of Dairy Science 76:1753-1771.

Palmquist, D. L. and Jenkins, T. C. 1980. Fat in lactation rations: Review. Journal of Dairy Science 63:1-14.

Paradis, C.; Berthiaume, R.; Lafreniere, C.; Gervais, R. and Chouinard, P. Y. 2008. Conjugated linoleic acid content in adipose tissue of calves suckling beef cows on pasture and supplemented with raw or extruded soybeans. Journal of Animal Science 86:1624-1636.

Park, H. S.; Ryu, J. H.; Ha, Y. L. and Park, J. H. Y. 2001. Dietary conjugated linoleic acid (CLA) induces apoptosis of colonic mucosa in 1,2-dimethylhydrazine-treated rats: a possible mechanism of the anticarcinogenic effect by CLA. British Journal of Nutrition 86:549-555.

Pires, A. V.; Eastridge, M. L.; Firkins, J. L. and Lin, Y. C. 1997. Effects of heat treatment and physical processing of cottonseed on nutrient digestibility and production performance by lactating cows. Journal of Dairy Science 80:1685-1694.

Reiser, R. and Fu, H. C. 1962. The mechanism of gossypol detoxification by ruminant animals. Journal of Nutrition 76:215-218.

Reveneau, C.; Ribeiro, C. V. D. M.; Eastridge, M. L. and Firkins, J. L. 2012. Interaction of unsaturated fat or coconut oil with monensin in lactating dairy cows fed 12 times daily. II. Fatty acid flow to the omasum and milk fatty acid profile. Journal of Dairy Science 95:2061-2069. 
Risco, C. A.; Adams, A. L.; Seebohm, S.; Thatcher, M. J.; Staples, C. R.; Van Horn, H. H.; McDowell, L. R.; Calhoun, M. C. and Thatcher, W. W. 2002. Effects of gossypol from cottonseed on hematological responses and plasma $\alpha$-tocopherol concentration of dairy cows. Journal of Dairy Science 85:3395-3402.

Santos, J. E. P.; Villasenor, M.; Robinson, P. H.; DePeters, E. J. and Holmberg, C. A. 2003. Type of cottonseed and level of gossypol in diets of lactating dairy cows: plasma gossypol, health, and reproductive performance. Journal of Dairy Science 86:892-905.

Schauff, D. J. and Clark, J. H. 1992. Effects of feeding diets containing calcium salts of long-chain fatty acids to lactating dairy cows. Journal of Dairy Science 75:2990-3002.

Schmidely, P.; Glasser, F.; Doreau, M. and Sauvant, D. 2008. Digestion of fatty acids in ruminants: a meta-analysis of flows and variation factors. 1. Total fatty acids. Animal 2:677-690.

Schroeder, G. F.; Delahoy, J. E.; Vidaurreta, I.; Bargo, F.; Gagliostro, G. A. and Muller, L. D. 2003. Milk fatty acid composition of cows fed a total mixed ration or pasture plus concentrates replacing corn with fat. Journal of Dairy Science 86:3237-3248.

Schroeder, G. F.; Gagliostro, G. A.; Bargo, F.; Delahoy, J. E. and Muller, L. D. 2004. Effects of fat supplementation on milk production and composition by dairy cows on pasture: a review. Livestock Production Science 86:1-18.

Smith, W. A.; Harris, B.; Van Horn, H. H. and Wilcox, C. J. 1993. Effects of forage type on production of dairy cows supplemented with whole cottonseed, tallow, and yeast. Journal of Dairy Science 76:205-215.

Sunvold, G. D. and Cochran, R. C. 1991. Technical note: Evaluation of acid detergent lignin, alkaline peroxide lignin, acid insoluble ash, and indigestible acid detergent fiber as internal markers for prediction of alfalfa, bromegrass, and prairie hay digestibility by beef steers. Journal of Animal Science 69:4951-4955.

Toral, P. G.; Belenguer, A.; Frutos, P. and Hervás, G. 2009. Effect of the supplementation of a high-concentrate diet with sunflower and fish oils on ruminal fermentation in sheep. Small Ruminant Research 81:119-125.

Toral, P. G.; Belenguer, A.; Shingfield, K. J.; Hervás, G.; Toivonen, V. and Frutos, P. 2012. Fatty acid composition and bacterial community changes in the rumen fluid of lactating sheep fed sunflower oil plus incremental levels of marine algae. Journal of Dairy Science 95:794-806.

Ueda, K.; Ferlay, A.; Chabrot, J.; Loor, J. J.; Chilliard, Y. and Doreau, M. 2003. Effect of linseed oil supplementation on ruminal digestion in dairy cows fed diets with different forage:concentrate ratios. Journal of Dairy Science 86:3999-4007.
Ulbricht, T. L. V. and Southgate, D. A. T. 1991. Coronary heart disease: seven dietary factors. The Lancet 338:985-992.

Van Knegsel, A. T. M.; van den Brand, H.; Dijkstra, J.; van Straalen, W. M.; Heetkamp, M. J. W.; Tamminga, S. and Kemp, B. 2007. Dietary energy source in dairy cows in early lactation: energy partitioning and milk composition. Journal of Dairy Science 90:1467-1476.

Van Soest, P. J.; Robertson, J. B. and Lewis, B. A. 1991. Methods for dietary fiber, neutral detergent fiber, and nonstarch polysaccharides in relation to animal nutrition. Journal of Dairy Science 74:3583-3597.

Váradyová, Z.; Kišidayová, S.; Siroka, P. and Jalc, D. 2008. Comparison of fatty acid composition of bacterial and protozoal fractions in rumen fluid of sheep fed diet supplemented with sunflower, rapeseed and linseed oils. Animal Feed Science and Technology 144:44-54.

Vasta, V.; Nudda, A.; Cannas, A.; Lanza, M. and Priolo, A. 2008. Alternative feed resources and their effects on the quality of meat and milk from small ruminants. Animal Feed Science and Technology 147:223-246.

Velasquez-Pereira, J.; Risco, C. A.; McDowell, L. R.; Staples, C. R.; Prichard, D.; Chenoweth, P. J.; Martin, F. G.; Williams, S. N.; Rojas, L. X.; Calhoun, M. C. and Wilkinson, N. S. 1999. Long-term effects of feeding gossypol and vitamin E to dairy calves. Journal of Dairy Science 82:1240-1251.

Villaseñor, M.; Coscioni, A. C.; Galvão, K. N.; Chebel, R. C. and Santos, J. E. P. 2008. Gossypol disrupts embryo development in heifers. Journal of Dairy Science 91:3015-3024.

Wilks, D. L.; Coppock, C. E.; Brooks, K. N. and Gates, C. E. 1991. Effects of differences in starch content of diets with whole cottonseed or rice bran on milk casein. Journal of Dairy Science 74:1314-1320.

Williams, A. G. 1986. Rumen holotrich ciliate protozoa. Microbiological Reviews 50:25-49.

Williams, C. H.; David, D. J. and Iismaa, O. 1962. The determination of chromic oxide in faeces samples by atomic absorption spectrophotometry. The Journal of Agricultural Science 59:381-385.

Yamasaki, M.; Kishihara, K.; Ikeda, I.; Sugano, M. and Yamada, K. 1999. A recommended esterification method for gas chromatographic measurement of conjugated linoleic acid. Journal of the American Oil Chemists' Society 76:933-938.

Yang, A.; Larsen, T.; Smith, S. and Tume, R. 1999. $\Delta^{9}$ desaturase activity in bovine subcutaneous adipose tissue of different fatty acid compositiondesaturase activity in bovine subcutaneous adipose tissue of different fatty acid composition. Lipids 34:971-978.

Zhang, W. J.; Xu, Z. R.; Pan, X. L.; Yan, X. H. and Wang, Y. B. 2007. Advances in gossypol toxicity and processing effects of whole cottonseed in dairy cows feeding. Livestock Science 111:1-9. 